Oт редакции: Публикуя материал американских юристов М.Хаймэн и Н.Баренбойм, редакция решила поместить на страницах МЖМП судебное решение по аналогичному предмету из российской практики, предварив его аналитическим комментарием.

\title{
Калашникова против Соединенных Штатов
}

\section{Р.Э. Дамиров}

Не секрет, что в дипломатических представительствах иностранных государств в России работает немало российских граждан. Также не секрет, что в отличие от прежних времен некоторые из них находят вакансии, минуя Главное управление по обслуживанию дипкорпуса при МИД РФ. Менее известны конфликтные ситуации, в которых оказываются наши сограждане, работающие на органы иностранных государств, каковыми являются указанные представительства. Нередко они предпочитают следование жестким правилам, установленным работодателем, потере стабильной и приличной зарплаты. Бывший преподаватель всемирно уважаемого московского вуза, ныне служащий в посольстве крупной державы, посетовав в беседе с'автором этих строк на унизительные условия, решительно отверг саму мысль о возвращении в академические сферы. Выполняемые им функции - ремесленничество по сравнению с тем, чему он учил своих студентов, однако получаемое жалование превышает заработок его бывшего коллеги - профессора, видного ученого, лауреата, почетного доктора иностранных университетов.

Конфликт, сторонами которого были Посольство США в Москве и жуналистка М.С. Калашникова - не просто исключение. Скандальным обстоятельствам сопутствовала не только публичность, но и юридическая процедура, в которой свои позиции высказали как суды обшей юрисдикцин, так и высшая инстанция - Конституционный Суд Российской Федерации.

Мы не будем исследовать всех фактических обстоятельствах дела, а при анализе вопросов права сосредоточим свое внимание на его международно-правовой стороне.

Факты. С 1 октября 1999 г. по 3 марта 2000 г. М.С. Калашникова работала ведущим специалистом информационной службы Посольства США в РФ, откуда была уволена по пункту 2 статьи 33 КЗОТ РФ (обнаружившееся несоответствие работника занимаемой долж- 
ности или выполняемой работе вследствие недостаточной квалификации либо состояния здоровья, препятствующих продолжению данной работы). При приеме на работу и увольнении в трудовой книжке М.С. Калашниковой были сделаны необходимые записи с указанием номера приказа, подписью начальника отдела кадров, была приложена печать Посольства. При этом в приказе, по которому М.С. Калашникова увольнялась с работы, в качестве основания было приведено именно "обнаружившееся несоответствие работника занимаемой должности"1.

Яркие детали процедуры увольнения стали достоянием средств массовой информацин. "Независимая газета", творческим сотрудником которой вскоре стала М.С. Калашникова, рассказала о том, как последняя "была препровождена со своего рабочего места прямо на улицу морским пехотинцем с автоматической винтовкой наизготовку... Началось же все с внезалного вызова к начальству, объявившего Калашниковой o "несоответствии занимаемой долюности" и тут же передавшему ее под конвой морпеха. Вся процедура - от вызова к шефу до момента, когда за нею захлопнулась дверь посольства, заняла менее часа"2.

М.C. Калашникова решила защищать свои права не только на страницах печати, но и в суде. За разрешением своего трудового спора она обратилась в Пресненский межмуниципальный суд г. Москвы, предъявив иск к Посольству США, требуя восстановления на работе, оплаты вынужденного прогула и возмешения морального ущерба. Однако определением суда первой инстанции от 27 марта 2000 г., оставленным без изменения судебной коллегией по гражданским делам Московского городского суда от 28 апреля 2000 г., жалобщице было отказано в принятии искового заявления. При этом суд сослался на ст. 435 ГПК РСФСР, часть первая которой устанавливала, что предъявление иска к иностранному государству допускается лишь с согласия компетентных органов соответствующего государства ${ }^{3}$. Документа, свидетельствующего о таком согласии, у М.С. Калашниковой не оказалось.

Примечательно, что судебная коллегия обратилась к международно-правовым источникам за аргументами в пользу своей позиции.

\footnotetext{
1 Копия имеется В распоряжении редакции.

2 К.Викторов. Морская пехота против КЗОТа. "Независимая газета", 18 марта 2000 г. 3 Дейсгвующая редакиия статьи 435 - см.: Ведомости Верховного Совета РСФСР, 1980, № 32, ст. 987.
} 
Отвергая ссылки заявителя на нормы Венской конвенции о дипломатических сношениях 1961 г., она заявила, что Конвенция "не обязывает Посольство США участвовать в рассмотрении гражданского дела на территории РФ без согласия компетентных органов США. Ст. 31 и $33^{4}$ Конвенции указывают на права и обязанности дипломатического агента, а не на обязанность Посольства на процессуальное представительство по гражданскому делу"5.

8 июня 2000 г. М.С. Калашникова обратилась в Конституционный Суд РФ с жалобой, в которой утверждала, что примененная в ее деле норма ГПК РСФСР ущемляла ее конституционное право ка судебную защиту. М.С. Калашникова обнаружила несоответствие этой нормы следующим положениям Конституции РФ: ч. 1 ст. 46 ("каждому гарантируется судебная защита его прав и свобод") ч. 1 ст. 47 ("никто не может быть лишен права на рассмотрение его дела в том суде и тем судьей, к подсудности которых оно отнесено законом") и ч. 3 ст. 55 ("права и свободы человека и гражданина могут быть ограничены федеральным законом только в той мере, в какой это необходимо в целях защиты основ конституционного строя, нравственности, здоровья, прав и законных интересов других лиц, обеспечения обороны страны и безопасности государства").

В своей жалобе М.С. Калашникова также ссылалась на п. "с" ч. 1 ст. 31 Венской конвенции о дипломатических сношениях, который заявитель понимала как указание на то, что "действия посольства США по найму российских граждан находятся в российской юрисдикции"6. Напомним, что указанным положением предусмотрено исключение из иммунитета дипломатического агента от гражданской и административной юрисдикции в случае "исков, относящихся к любой профессиональной или коммерческой деятельности, осуществляемой дипломатическим агентом в государстве пребывания за пределами своих официальных функций"7 . В обоснование своей позиции М.С.Калашникова приводила тот факт, что Посольство США взимало с нее "налоги в доход РФ, производило все виды отчислений в социальные фонды РФ". Наконец, в качестве аргумента

\footnotetext{
4 Так в орнгинале, хотя в действительности должна быть указана статья 32 Конвенции - Р.Д.

5 Копия имеется в распоряжении редакции.

6 Копия имеется в распоряжении редакции.

7 Сборник действующих договоров, соглашений и конвенций, заключенных СССР с иностран-ными государствами. Выпуск XXIII, М., 1970. С.142.
} 
она упомянула некий советско-американский "Договор о взаимном признании гражданских исков от 1964 г."

Право. Начнем с простого. Ссылка М.С. Калашниковой в обоснование своей позиции на то, что Посольство США взимало с нее "налоги в доход РФ, производило все виды отчислений в социальные фонды РФ" не является убедительной. В силу ч. 2 ст. 23 Венской конвенции о дипломатических сношениях "фискальные изъятия, (предоставляемые принимающим государством аккредитующему государству и дипломатическому представительству - Р.Д.), не касаются тех налогов, сборов и пошлин, которыми, согласно законам государства пребывания, облагаются лица, заключающие контракты с аккредитующим государством или главой представительства"8.

Договор между СССР и США о взаимном признании гражданских исков 1964 г., на который ссылается М.С.Калашникова, в официальном источнике - Сборнике действующих договоров и конвенций. заключенных СССР с иностранными государствами, автору этих строк обнаружить не удалось.

Теперь о более сложном. Оспариваемой М.С. Калашниковой ст. 435 ГПК РСФСР первоначально в советское, а ныне в российское внутригосударственное право трансформированы нормы международного права об иммунитете государства и о дипломатическом иммунитете. Иммунитет государства является общепризнанным принципом международного права и происходит от государственного суверенитета и суверенного равенства государств. Такой вид иммунитета распространяется на органы государств, каковым является его дипломатическое представительство. Принцип иммунитета государства применительно к последнему конкретизирован в Венской конвенции о дипломатических сношениях 1961 г. Необходимо пояснить, что как иммунитет государства, так и дипломатический иммунитет существовали в виде международно-правового обычая задолго до кодификации в Венской конвенции.

Таким образом, в положении ГПК РСФСР, конституционность которого была поставлена под сомнение М.С.Калашниковой, воплотилась норма международного права, отвечающая обоим критериям принадлежности к российской правовой системе, сформулированным в ч. 4 ст. 15 Конституции РФ: это трансформированный во внутригосударственное право международно-правовой обычай, являю-

${ }^{8}$ Там же. С. 141 
щийся общепризнанным принципом международного права и одновременно нормой международного договора, в который этот обычай был кодифицирован.

Поэтому к оспариваемому М.С.Калашниковой положению - ст. 435 ГПК РСФСР - претензии с точки зрения его конституционности едва ли были обоснованы.

А что, если проблема была в другом: ст. 435 была неверно понята истцом и неправильно применена судами общей юрисдикции?

Как известно читателю, в доктрине и практике международного права встречаются концепции абсолютного и ограниченного, или функционального, иммунитета государства. Согласно первой, государство не может быть привлечено к суду другого государства в качестве ответчика, кроме случаев определенно выраженного согласия на это. Согласно второй концепции, иммунитет государства признается при осуществении им суверенных, или публичных актов (јure imperii), но не в отношении частных актов (jure gestionis). Венская конвенция о дипломатических сношениях в части, предписывающей иммунитеты, основана на сочетании обеих концепций.

Согласно ч.1 ст.31 Венской конвенции, "дипломатический агент нользуется иммунитетом от уголовной юрисдикции государства пребывания. Он пользуется также иммунитетом от гражданской и административной юрисдикции, кроме случаев:

а) вещных исков, относящихся к частному недвижимому имуществу, находящемуся на территории государства пребывания, если только он не владеет им от имени аккредитующего государства для целей представительства;

b) исков, касающихся наследования, в отношении которых дипломатический агент выступает в качестве исполнителя завещания, попечителя над наследственным имуществом, наследника или отказополучателя как частное лицо, а не от имени аккредитующего государства;

с) исков, относящихся к любой профессиональной или коммерческой деятельности, осуществляемой дипломатическим агентом в государстве пребывания за пределами своих официальных функций"9 .

Согласно ч. 1 ст. 32 Венской конвенции "от иммунитета от юрисдикции дипломатических агентов... может отказаться аккредитующее государство" 10 .

\footnotetext{
9 Там же. C. 142.

10 Там же
} 
При этом в ч. 2 той же статьи содержится уточнение: "Отказ должен быть всегда определенно выраженным"lI.

М.С. Калашниковой предьявлен иск к Посольству США, а это орган иностранного государства. Иск возник в связи с деятельностью Посольства, которая может быть охарактеризована как "публичный акт". Такие иски международным правом не допускаются. Даже если бы М.С. Калашникова предъявила иск не к Посольству США, а к конкретному дипломатическому агенту, п.п. "a" и "b" ч. 1 ст. 31 к ее жалобе не могли бы быть применены, поскольку касаются иных правоотношений.

Если исходить из того, что наем на работу в дипломатическое представительство персонала из числа граждан страны пребывания непосредственно связан с выполнением посольством своих официальных функций, то и п. "с" также не может быть применен в данном случае, а значит ссылка на него в жалобе М.С. Калашниковой необоснованна.

Получается, что Венская конвенция оставляла М.С. Калашниковой две возможности: либо обратиться к Правительству США с требованием об отказе от иммунитета от юрисдикции конкретного дипломатического агента, с которым она заключила контракт, либо направить иск в суд в США. Последнее допускается ч. 4 ст. 31 Венской конвенции, в соответствии с которой "иммунитет дипломатического агента от юрисдикции государства пребывания не освобождает его от юрисдикции аккредитующего государства"12.

Однако обращает на себя внимание то обстоятельство, что российская гражданка М.С. Калашникова была уволена с работы в иностранном учреждении на основании КЗОТ РФ, о чем в ее трудовой книжке сделана соответствующая запись. Не зная условий контракта, а копия его не была представлена в суд, трудно судить, почему иностранный работодатель, являющийся органом государства, а не коммерческой компанией, решил применить российский закон. Суды общей юрисдикции, рассматривавшие иск М.С. Калашниковой, не обратили внимания на это обстоятельство, сосредоточившись на недопустимости предъявления иска к иностранному государству.

И здесь возникает сразу несколько вопросов: применив законодательство страны пребывания как при найме, так и при увольнении М.С. Калашниковой, не отказалось ли иностранное государство в

11 Там же.
12 Там же. 
лице его органа от иммунитета в отношении гражданской юрисдикции применительно к данному конкретному случаю? Не означает ли это, что орган иностранного государства, каковым является посольство, согласился, что применимым правом является право страны пребывания? Если это так, не равносильно ли такое согласие пусть разовому, применительно лишь к данному конкретному случаю (или к ограниченной и строго определенной категории случаев), но все же отказу от иммунитета от гражданской юрисдикции страны пребывания? Нельзя ли рассматривать применение Посольством США при увольнении М.С. Калашниковой российского закона как выраженный отказ от иммунитета от гражданской юрисдикции применительно к трудовому спору?

Суд. Нам не дано знать, как вырабатывалась позиция Конституционного Суда РФ по жалобе М.С. Калашниковой - что поделаешь, тайна совещательной комнаты. Суд рассматривал ее на пленарном заседании в присутствии всех девятнадцати судей. Трудно сказать, почему так случилось, ведь Федеральный конституционный закон "О Конституционном Суде Российской Федерации" предполагает рассмотрение таких вопросов в заседаниях палат ${ }^{14}$ хотя в пленарном заседании Суд может рассмотреть любой вопрос, входящий в его компетенцию 14 . Споры ли были слишком горячими и палата не смогла придти к согласию, а потому передала вопрос на рассмотрение пленуму? Или же Суд сразу решил рассматривать жалобу полным составом, задумавшись о том, что наряду с анализом поставленных в жалобе вопросов права, ему придется принимать во внимание последствия, хотя бы и отдаленные, его решения для взаимоотношений российских дипломатических представительств в США с государственными органами и гражданами страны пребывания? А может быть палаты в тот момент просто оказались перегружены делами.

Есть версия, что некоторая часть суда якобы имела намерение строить свою правовую позицию на существующей, по ее мнению, в международном праве тенденции ограничения случаев, в которых государство может ссылаться на иммунитет в иностранных судах, ссылаясь при этом на европейскую Конвенцию об иммунитете государств 1972 г.

13 Пункт 3 части второй статьи 22. См.: Собрание законодательства РФ, 25 июля 1994 г., № 13, ст. 1447.

14 Часть первая статьи 21 ФКЗ "О Конституционном Суде Российской Федерации". 
Трудно судить, насколько уместной была бы такая аргументация, если бы ее воспринял Суд. Вспомним, ведь незадолго до рассмотрения Конститушионным Судом РФ жалобы М.С. Калашниковой во Франции была предпринята попытка ареста российского учебного судна "Седов", там же арестовывались счета российских учреждений, в прессе упоминались угрозы ареста государственного воздушного судна, на котором совершает полеты Президент РФ, на что российская сторона реагировала весьма болезненно. С друтой стороны, когда МИД РФ обратилось в Посольство США с просьбой официально разъяснить условия увольнения М.С. Калашниковой и представить необходимые документы, Посольство ответило отказом, ссылаясь на неприкосновенность своих архивов и документов, гарантированную статьей 24 Венской конвенции о дипломатических сношениях ${ }^{15}$.

Если же упомянутая тенденция действительно просматривалась, следовало бы оценить ее выгодность или невыгодность для Российской Федерации. Если же она невыгодна, едва ли Конституционному Суду пристало бы освяшать ее своим решением.

Да и ссылка в качестве авторитетного аргумента на европейскую Конвенцию об иммунитете государств едва ли была бы уместной. Вопервых, Россия в ней не участвует. Во-вторых, ко дню принятия решения по жалобе М.С. Калашниковой из 41 государства, состоявшего на тот момент членом Совета Европы, в этой Конвенции участвовало восемь, при этом последняя ратификация состоялась в 1990 г.

Впрочем, такой подход в Суде не возобладал.

Решение, принятое Конституционным Судом РФ по жалобе М.С. Калашниковой, в практике этого судебного органа именуется "содержательным определением". Это не постановление по существу предъявленного Суду вопроса права, но и не отказ от его рассмотрения по формальным основаниям. Принимая такие определения, Конституционный Суд высказывает мотивированную правовую позицию. Эта правовая позиция не только обязывает правоприменителя, но и содержит аргументированную юридическую подсказку заявителю и судам.

Подобные подсказки нетрудно найти и в данном решении. Просвещенный читатель наверняка обратит внимание на те пассажи в п. 3 Определения, где говорится о самоустранении судов общей юрисдикцин от исследования вопроса о том, могло ли применение трудо-

15 Копия перевода на русский язык ноты Посольства США имеется В распоряжении редакции. 
вого законодательства страны пребывания рассматриваться в качестве частичного отказа иностранного посольства от иммунитета в отношении гражданской юрисдикции, или же где указывается на недопустимое ограничение права заявительницы на индивидуальный трудовой спор, или же где сказано о лишении ее возможности осуществить право на восстановление на работе. При этом Конституционный Суд, критикуя позицию судов общей юрисдикции, не скрывает своего отношения к действиям бывшего работодателя М.С. Калашниковой.

В заключение отметим, что в данном решении Конституционный Суд РФ не формально цитировал международно-правовые источники, привлекая их в качестве украшения или довеска к уже сформулированной позиции, как это порой случается в его практике, а органично вплетал их в ткань своей аргументации. 